\title{
LANGUAL PROGRAM AS AN INFORMATION BASE IN FOOD PRODUCT IDENTIFICATION PRACTICE
}

\author{
Buhyna L.M., Pallah O.V., Meleshko T.V., Rukavchuk R.O., Bati V.V. \\ ПРОГРАМА LANGUAL ЯК ПНФОРМАЦЙНА БАЗА У ПРАКТИЦІ \\ ІДЕНТИФЫКАЦІЇ ПРОДУКТІВ ХАРЧУВАННЯ
}

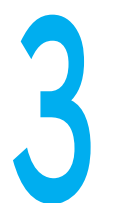

БУГИНА Л.М., ПАЛЛАГ О.В., МЕЛЕШКО Т.В., РУКАВЧУК Р.О., БАТI В.В.

Ужгородський національний університет, м. Ужгород, Україна начні зміни у структурі та якості системи харчування в усьому світі призвели до того, що традиційні дієти поступово модифікуються під впливом суміжних харчових культур. Це проявляється у появі великої кількості багатих на вуглеводи та жири кулінарно-оброблених продуктів. Зростання урбанізації разом з інформатизацією та комп'ютеризацією багатьох сфер промисло- вості призвело до значного «знерухомлення» населення зі скороченням енергетичних витрат [1]. Наслідком цього $€$ збільшення частоти виникнення некомунікативних захворювань, таких як метаболічний синдром, ожиріння, серцево-судинні захворювання та алергії [2].

Важливою також є безпека харчових продуктів і продовольчої сировини, які нале-
ПРОГРАМА LANGUAL ЯК ІНФОРМАЦІЙНА БАЗА У ПРАКТИЦІ ІДЕНТИФІКАЦІЇ

ПРОДУКТІВ ХАРЧУВАННЯ

Бугина Л.М., Паллаг О.В., Мелешко Т.В., Рукавчук Р.О., Баті В.В.

Ужгородський національний університет, м. Ужгород, Україна

Чітко структурований ієрархічний словник, пов'язаний з логічними і об'єктивними відносинами у сфері споживання харчових продуктів, іншими словами, з їхньою онтологією вкрай необхідний для вирішення проблем гармонізації сучасних даних, які охоплюють сферу продовольчої безпеки, сертифікованої якості, технології виробництва, розподілу, а також здоров'я і комфорту кінцевих споживачів їжі. Мета. Проаналізувати сучасний стан процесу розробки стандартизованих і комп'ютеризованих систем класифікації продуктів харчування, які підключаються до існуючих сучасних баз даних та надають інформацію про склад та нутриціологічні характеристики харчових продуктів у режимі реального часу.

Методи. Теоретичний синтез і дедуктивний аналіз, літературний огляд зарубіжних наукових рецензованих джерел.

Результати. 3'ясовано, що відсутність єдиної і зрозумілої цифрової мови є наявним упущенням у сфері комп'ютеризації та уніфікації інформації про продукти харчування, оскільки харчові об'єкти безперервно переміщаються від їхнього природного або фермерського походження технологічними ланцюгами обробки та розподілу до споживачів, локалізованих на різних континентах, які мають різні нутриціологічні потреби та фізіологічні запити, і можуть відрізнятися у різних країнах світу. Ключові слова: продукти харчування, безпека, LanguaL, EuroFIR, FoodON.

\section{LANGUAL PROGRAM AS AN INFORMATION BASE IN FOOD PRODUCT IDENTIFICATION PRACTICE \\ Buhyna L.M., Pallah O.V., Meleshko T.V., Rukavchuk R.O., Bati V.V. \\ Uzhhorod National University, Ukraine}

Background: A clearly structured hierarchical vocabulary related to logical and qualitative relationships in the field of food consumption, in other words, with their ontology, is extremely necessary to solve the problems of data harmonization which cover areas of food safety, certified quality, production technology, distribution, as well as health and comfort of the end-users of food.

Objective: We analyzed the current state of the process of the development of standardized and computerized food classification systems that are connected to existing modern databases and provide real-time information on the composition and nutritional features of foods.

Methods: We used the methods of theoretical synthesis and deductive analysis, literary review of foreign scientific reviewed sources.

Results: The lack of a single and understandable digital language was found to be an obvious gap in the field of $C$ omputerization and unification of information on food products, as food objects are constantly moving from their natural or farm origin, through the technological processing and distribution chains to the consumers on different continents that are characterized by various nutritional and physiological needs that may differ in the countries throughout the world.

Keywords: food safety, Langual, EuroFIR, FoodON.

๔ Бугина Л.М., Паллаг О.В., Мелешко Т. В., Рукавчук Р. О., Баті В.В. СТАТТЯ, 2020. 
жать до основних факторів, що визначають здоров'я населення України і збереження його генофонду, адже понад 70\% усіх забруднювачів надходять до організму людини з продуктами харчування [3]. Стан справ з безпекою продовольства в Україні, особливо останніми роками, погіршився у зв'язку з демонополізацією харчової промисловості, збільшенням обсягів постачань 3-за кордону, ослабленням контролю над виробництвом і реалізацією продуктів харчування. Тому знання базових характеристик існуючих на ринку збуту харчових продуктів, таких як склад, технологічні та кулінарні особливості обробки, а також їхній вплив на фізіологічні процеси в організмі людини - актуальна і дискусійна проблема сучасної нутриціології, яка перебуває на межі інших наук - хімії, мікробіології, медицини та інших, роблячи це питання міждисциплінарним та мультимодальним за своєю сутністю.

Крім того, однією з ключових проблем $€$ складність у повсякденному виборі їжі для споживання. Покупець стає більш нерішучим, коли стикається 3 великою кількістю продуктів харчування, при цьому він має мало інформації про їхні інгредієнти і технологічні процеси, яким вони піддавалися [4]. З розвитком інформаційних технологій з'явилася велика кількість програм, які надають можливість підключення до різноманітних баз даних, що містять інформацію про вміст поживних речовин, біологічну та енергетичну цінність продукту. Проте для їхнього повноцінного функціонування необхідна наявність стандартизованих та комп'ютеризованих систем класифікації продуктів харчування.

Мета. Вивчити сучасний стан процесу розробки стандартизованих і комп'ютеризованих систем класифікації продуктів харчування, які підключаються до існуючих су-

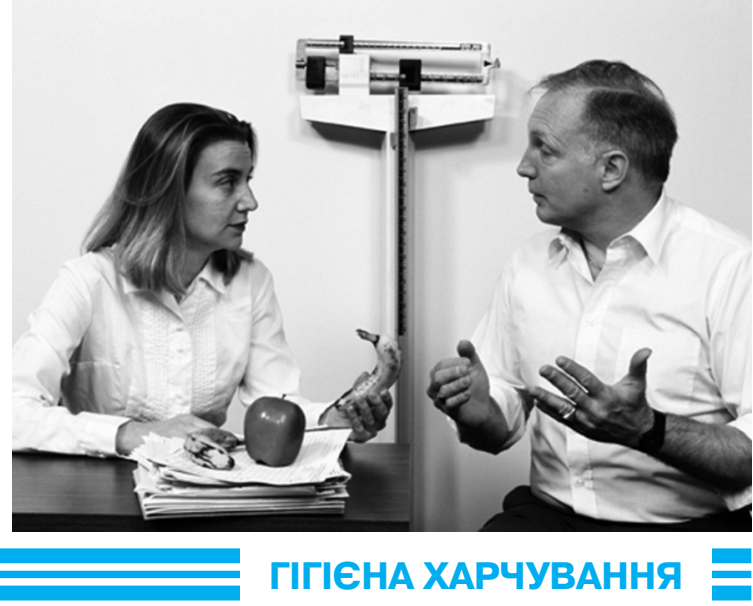

часних баз даних і дають інформацію про склад харчових продуктів у режимі реального часу.

Методи. Теоретичний синтез і дедуктивний аналіз, літературний огляд зарубіжних наукових рецензованих джерел.

Результати та обговорення. Існуючі ініціативи, спрямовані на споживача харчових продуктів та на формування його об'єктивного знання у режимі реального часу (тобто під час купівлі їжі) про склад продуктів харчування, є вкрай актуальними й важливими і потребують постійного удосконалення та модифікації. Колосальна кількість населення, що страждає на харчову алергію, щодня купує продукти, не знаючи про справжній їхній склад, ризикуючи спровокувати алергічну реакцію, особливо під час споживання багатокомпонентних продуктів харчування [5].

$\mathrm{Ha}$ сьогоднішній день в Європі розроблено багато різних баз даних харчових продуктів, наприклад Eurofoods, CEECFOODS, NORFOODS тощо. Європейський Союз створив програму 3 наукових досліджень їжі EuroFIR. Нині це провідна світова інформаційна база даних про склад їжі. Мета EuroFIR полягає у розробці, публікації та використанні інформації про склад харчових продуктів, а також у розвитку міжнародного співробітництва та гармонізації стандартів у підвищенні якості відповідних даних, їх збереження та доступу. EuroFIR AISBL надає найкращу на- вявну інформацію про харчові продукти в усьому світі, об'єднуючи 26 організаційкомпіляторів в Європі, США та Канаді (FoodEXplorer), а також надає достовірну інформацію про біологічно активні сполуки (eBASIS). В її рамках було створено спеціальну програму для опису їжі - Langual (Languaa Limentaria), яка $є$ найбільш розвиненою й уніфікованою системою та надає можливість описати найдрібніші деталі і характеристики харчових продуктів.

Саме для цієї програми розроблено низку спеціальних класифікацій продуктів харчування, систем шифрування і кодифікації, які дозволяють однозначно ідентифікувати продукти. Мова «Languaа Limentaria» - це автоматизована система, яка описує, зберігає, систематизує і відновлює дані про склад їжі. Ця багатомовна і заснована на тезаурусі інтелектуальна база даних модернізується й удосконалюється 3 кожним роком. Кожна страва у цій системі описується набором стандартних і контрольованих термінів, обраних з тих аспектів, які характеризують якість харчових продуктів, гігієнічні та органолептичні властивості.

Дані аспекти містять також спеціальні дескриптори, інформуючи про походження, технологію обробки, приготування, методи збереження і географічне походження того чи іншого продукту. На даний час тезаурус багатомовний (чеська, датська, англійська, французька, німецька, італійська, португальська, іспансь- 
FoodOn (http://foodon.org) - це перший проект, який використовує Langual, при цьому його управління здійснюється консорціумом зі створення всеосяжної і легкодоступної глобальної онтології «від ферми до виделки», яка точно і послідовно описує широко відомі у культурах усього світу страви. FoodOn намагається усунути прогалини у термінології харчових продуктів і підтримує реальне «відстеження» продуктів харчування. Зосередивши увагу на описі харчових продуктів для людини і домашніх тварин, FoodOn містить інформацію про основні джерела рослинної і тваринної їжі, їхні базові властивості, а також інші важливі аспекти, такі як процеси консервації, контактні поверхні та упаковка (тара) [7].

Велика частина словника FoodOn походить від перетворення Langual, роблячи їх у своїй сукупності єдиним зрілим тезаурусом для продуктів харчування, доповнює словник у форматі OWL (Web Ontology World Wide Web Consortium), забезпечуючи функціональну сумісність системи, контроль якості та програмну складову [8].

У рамках міжнародного проекту «Збір та внесення аналітичних даних складу продуктів харчування регіонів Європи і Центральної Азії» та у тісній співпраці з постійним партнером - мережею EuroFIR (http://www.eurofir.org/) - фахівцями нашого центру зібрано перші 100 харчових продуктів України, які внесені до національних баз даних складових їжі «Продовольчої та сільськогосподарської організації Об'єднаних Націй» (Food and Agriculture Organization of the United Nations (FAO). Як джерела даних використовувалися наукові статті, що містили аналітичні дані, звірені відповідно з нормативною документацією. Дані про склад обраних продуктів харчування входять до реєстру FAO та доступні для громадсь- кості у мережі Інтернет (http://www.fao.org/home/en/). Метою FAO є підтримка країни для створення баз даних, які будуть вільно доступні для кінцевих користувачів в окремих країнах і за кордоном, а також може служити як основа для розробки повноцінної функціонуючої національної бази даних поживного складу харчових продуктів відповідно до міжнародних стандартів.

\section{Висновки}

Програма Langual $€$ надзвичайно перспективним інструментом у практиці ідентифікації продуктів харчування. Ї̈̈ використання $€$ де-факто стандартом під час створення баз даних їжі. Проте в Україні вона майже не використовується, у тому числі через відсутність перекладу на українську мову. Тому, зважаючи на світовий досвід, актуальним $€$ створення універсальної бази даних про склад харчових продуктів в Україні з використанням Langual, за допомогою якої можна буде розробити чіткі щоденники та плани харчування залежно від стану пацієнта. Ця база даних має враховувати усі регіональні особливості харчування і харчових продуктів, постійно оновлюватися, розширюватися та удосконалюватися. Одним 3 наступних актуальних завдань $є$ узгодження цієї регіональної бази даних з відомими базами даних EuroFIR та електронними ресурсами.

ЛІТЕРАТУРА

1. Ireland J., Mwller A What's New in LanguaL ${ }^{\mathrm{TM}}$ ? Procedia Food Science. 2013. Vol. 2. P. 117-121.

2. Al-Mawali A. Non-communicable diseases: shining a light on cardiovascular disease, Oman's biggest killer. Oman Medical Journal. 2015. Vol. 30 (4). P. 227.

3. Дубініна А.А., Овчиннікова І.Ф., Петрів В.О. Визначення вмісту важких металів у виноградному вині «Кагор» вітчизняного виробспоживачів [6]. 
ПРОГРАМMA LANGUAL КАК ИНФОРМАЦИОННАЯ БАЗА В ПРАКТИКЕ ИДЕНТИФИКАЦИИ ПРОДУКТОВ ПИТАНИЯ

Бугина Л.М., Паллаг А.В., Мелешко Т.В., Рукавчук Р. О., Бати В.В.

Ужгородский национальный университет, г. Ужгород, Украина

Четко структурированный иерархический словарь, связанный с логическими и объективными отношениями в сфере потребления пищевых продуктов, другими словами, с их онтологией, крайне необходим для решения проблем гармонизации современных данных, охватывающих сферу продовольственной безопасности, сертифицированного качества, технологии производства, распределения, а также здоровья и комфорта конечних потребителей пищи.

Цель. Проанализировать современное состояние процесса разработки стандартизированных и компьютеризированных систем классификации продуктов питания, которые подключаются к существующим современным базам данных с информацией о составе и характеристике пищевых продуктов в режиме реального времени.

Методы. Теоретический синтез и дедуктивный анализ, литературный обзор зарубежных научных рецензируемых источников.

Результаты. Установлено, что отсутствие единого и понятного цифрового языка есть серьезным упущением в сфере компьютеризации и унификации информации о продуктах питания, поскольку пищевые объекты естественного происхождения непрерывно перемещаются по технологическим цепям обработки и распределения к потребителям, локализованным на разных континентах и имеющим различные нутрициологичные потребности и физиологические запросы, которые могут отличаться в разных странах мира.

Ключевые слова: продукты питания, безопасность, LanguaL, EuroFIR, FoodON. ництва. Прогресивні техніка та технології харчових виробництв ресторанного господарства і торгівлі : зб. наук. праць. Харків, 2012. Вип. 1. С. 224-229. URL: http://nbuv.gov.ua/UJRN/Pt_2 012_1_36.

4. Griffiths E.J., Brinkman F., Doolay D., Hsiao W. et al. FoodON: A Global Farm-toFork Food Ontology. ICBO/BioCreative. 2016. P. 202-209.

5. Albukhitan S., Helmy T. Multilingual food and health ontology learning using semistructured and structured Webdata sources.

Proceedings of the The 2012 IEEE/WIC/ACM International Joint Conferences on Web Intelligence and Intelligent Agent Technology. Vol. 03 IEEE Computer Society. 2012. P. 231-235.

6. Westenbrink S., Roe M., Oseredczuk M., Castanheira I., Finglas P. EuroFIR quality approach for managing food composition data; where are we in 2014?

Foodchemistry. 2016.

Vol. 193. P. 69-74.

7. Koval N., Pauk A., Buhyna L., Costa H. et al. Development of a national food composition data base in Ukraine following EuroFIR and
BaSeFood projects. Traditional Food International Congress (4-5 October 2012). 2012. P. 120-122.

8. Alghamdi D.A., Dooley D.M., Gosal G., Griffiths E.J.,

Fiona S.L. et al. FoodOn:

A Semantic Ontology

Approach for Mapping

Foodborne Disease Metadata. ICBO. 2017. P. 205-206.

REFERENCES

1. Ireland J. And Mwller A. Procedia Food Science. 2013 ; 2 : 117-121.

2. Al-Mawali A. Oman Medical Journal. 2015 ; 30 (4) : 227.

3. Dubinina A.A., Ovchynnikova I.F. and Petriv V.O. Vyznachennia vmistu vazhkykh metaliv u vynohradnomu vyni «Kahor» vitchyznianoho vyrobnytstva [Determination of Heavy Metals Content in Cahors Grape Wine of Domestic Production]. In : Prohresyvni tekhnika ta tekhnolohii kharchovykh vyrobnytstv restorannoho hospodarstva i torhivli [Progressive Engineering and Technology of Food Production Enterprises, Catering Business and Trade]. Kharkiv; 2012 ; 1 : 224-229. URL: http://nbuv.gov.ua/ UJRN/Pt 2012136

(in Ukrainian).
4. Griffiths E.J., Brinkman F., Doolay D., Hsiao W. et al. FoodON: A Global Farm-toFork Food Ontology. ICBO/BioCreative. 2016 : 202-209.

5. Albukhitan S. and Helmy T. Multilingual Food and Health Ontology Learning Using Semi-Structured and Structured Webdata Sources. In : Proceedings of The 2012 IEEE/WIC/ACM International Joint Conferences on Web Intelligence and Intelligent Agent Technology. Vol. 03 IEEE Computer Society. 2012 : 231-235.

6. Westenbrink S., Roe M., Oseredczuk M., Castanheira I. and Finglas P. FoodChemistry. 2016 ; 193 (15) : 69-74.

7. Koval N., Pauk A., Buhyna L., Costa H. et al. Development of a National Food Composition Data Base in Ukraine Following EuroFIR and BaSeFood Projects. In : Traditional Food International Congress (4-5 October 2012). 2012 : 120-122.

8. Alghamdi D.A., Dooley D.M., Gosal G., Griffiths E.J., Fiona S.L. et al. FoodOn: A Semantic Ontology Approach for Mapping Foodborne Disease Metadata. ICBO. 2017 : 205-206.

Надійшло до редакції 12.11.2019 